\title{
CONCEPTUAL ANALYSIS AND VARIATION IN BELIEF TRADITION: A CASE OF DEATH- RELATED BEINGS
}

\section{Kaarina Koski}

\begin{abstract}
The article focuses on the popular conceptualisation of a death-related agent which is known in Finnish folk belief and narratives by the name churchyard-väki (väki means 'crowd', but also 'power' in Finnish). Natural conceptualisation is economical and distinctions are only made when found relevant enough. Verbal descriptions of churchyard-väki's appearance and actions towards people vary remarkably according to the narrative context. Rather than a clearly defined supernatural agent, churchyard-väki is a complex of different ideas which have had enough similar features to form a single polysemous concept. The incoherence and context-bound variation of the concept imply that the status of churchyard-väki has been instrumental rather than constitutive in belief tradition.

In folk belief, churchyard-väki usually represents the other world's intrusion into this world. As an instrument of conveying intended messages, churchyard$v \ddot{a} k i$ has been used both in local gossip and traditionally formed discussions about morally charged questions. I have distinguished between three mental models, which have dominated the normative discussion about the relations between this and the other world. The question is about the ambivalence of the otherworldly impact and whether people are allowed or not to get actively involved with the supernatural. Belief legends about a sorcerer in the church at night make use of all the three models.
\end{abstract}

Key words: belief tradition, conceptual analysis, prototype theory, mental models, variation

Vernacular tradition with supernatural content can be studied from several different angles. My approach to Finnish belief narratives about death-related beings and powers focuses on concepts, contexts and, consequently, meaning. The aim of this paper is to explore how people manage with concepts which transform in different contexts and even provide contradictory interpretations. I will apply especially George Lakoff's (1987) and Talmy Givón's (1989) views on the prototype theory on polysemous concepts. My aim is to understand the relationship between narratives and worldviews on a collective level. 
In Finnish belief tradition, kirkonväki - here translated as churchyard$v \ddot{a} k i$ (sg.) - is a crowd of supernatural beings, which is closely related to death and church, and which sometimes functions as an invisible force. Since churchyard-väki has several synonyms, part of them metaphorical, local or idiosyncratic, this phenomenon cannot be identified by its name. ${ }^{1}$ Similarly remarkable variation, which is not in correlation with the variation of names, prevails also in descriptions of the appearance and actions of the agent. This raises the question of how to define this object of study? However, a far better question would be whether the definitions of the beings were of any consequence for the people who talked about them? This has led me to explore the conceptualisation of otherworldly phenomena in folk tradition. Having found the concept of churchyard-väki nebulous and contradictory, I will pose the question of its status in and contribution to the worldview. My point is that more important than the beings is the way they are approached in tradition.

In narratives, churchyard-väki appear in graveyards, on the road or even in farmhouses after someone has died or when death-related objects have been brought to the house. Belief legends also tell about their nightly church services. Some people describe churchyard-väki as decomposing bodies, while others tell it is an airy swarm of small, humanlike figures which reek of death. Many accounts present it as an invisible agent which is brought along in the form of a small amount of graveyard soil to haunt a house. Even though this account has regional variations, all these representations are known in the core of the tradition. ${ }^{2}$

Narratives and beliefs about churchyard-väki were still known and used in Finnish rural culture in the first half of the 20th century. During the rapid changes in the rural life of Finland, the tradition practically disappeared. My research material has been collected mostly during the first half of the 20th century. The recording of the material was carried out by scholars as well as by more or less experienced laymen under the supervision of the Finnish Literature Society (FLS). From the belief narrative collections held in the Folklore Archives of FLS, I have selected to my research corpus well over two thousand entries of different kinds of narratives as well as non-narrative information about the appearing of death-related beings as a crowd or a contagious deathrelated force. In The Type and Motif Index of Finnish Belief Legends and Memorates (Jauhiainen 1998) these materials mainly belong to numbers C 271, C 1101-C 1126, C 1301-C 1341, C 1061-C 1871 and D 301-D 400.

The narrative material consists of memorates and belief legends, the latter group comprising both local belief legends and internationally known fabulates. In addition to these genres, there are narratives about the local population 
and their habits and experiences, which often fall under the category of rumours. Such narratives are not traditional per se but often make use of traditional motifs and beliefs. Furthermore, churchyard-väki is known in incantations and ritual practices which the non-narrative information occasionally refers to. However, väki generally cannot be found in fairy tales or religious legends.

In a large corpus of narrative material the question whether narrators have believed in these beings and forces that they describe loses much of its relevance. If belief is defined as an active and conscious reliance on a certain ontological and, consequently, normative option, attitudes towards the belief content in these narratives would rather be characterised as a varying degreeto which these are being taken seriously or not. Or if folk belief is defined as part of the worldview on the basis of which people make their interpretations and inferences about their everyday life, this would not apply to all these narratives. Most of these narratives aim to discuss important or even sensitive issues in social life. They may be concerned with the relationship between the living and the dead and emphasise proper ways to cope with things related to death. Despite the relation to death, many of the narratives are actually not about death at all, but are rather concerned with acceptable versus socially disapproved activities. But even if the textual level was inconsistent with folk belief, the message that it conveys may be consistent with it and even be regarded as an important argument in the local social reality.

Narrative style or genre determines the interpretation of these representations. Fabulates typically speak about something other than can be seen on the textual level, and are thus given a symbolic rather than a literal interpretation. Even fictive or obsolete belief items can be applied in the interest of the plot, because details and their possible plausibility are subordinate to the message of the legend. Especially when belief legends are adapted to the local milieu and the motifs connected to the local people, they have a closer relationship with local beliefs also on the textual level. The emergence of belief items in legends reinforces their status in folk belief, and similarly, folk belief motifs legitimate the message of the legend (Tangherlini 1990: 380).

In the following passages my intention is to show the range of differences and similarities in the descriptions of churchyard beings, and apply cognitive linguistics to explain how such a popular concept is being constructed. Here, for the sake of English-speaking readers, I will leave out the linguistic analysis of synonymous and near-synonymous words denoting churchyard-väki and their different semantic connotations in Finnish. ${ }^{3}$ Instead, variation in the descriptions of the supernatural agents is here combined with the varying normative attitudes linked to the supernormal. First, however, I will charac- 
terise the idea of $v \ddot{a} k i$, which is the part that most of the conceptual variation stems from.

\section{VÄKI AS THE TRADITIONAL AND SCHOLARLY CONCEPT}

Supernatural agents which are interpreted as both beings and a power, are in Finnish folk belief called väki. In modern Finnish, the general meaning of the word is a crowd of people, but in other Finnic languages its equivalents denote force or power (Vilkuna 1956: 19-21). In belief narratives, the idea of power and beings are often mixed and intermingled. The impact of the power is explained by the action of invisible beings. Väki force is also known in Orthodox Karelia, but compared to Lutheran Finland, it is there seldom interpreted as a crowd of beings but rather as an essence or intentional nature of the entity in which it resides.

Several different väkis are either implicitly or explicitly present in narratives and ritual practices, some of them more powerful and significant than others. Natural elements such as the earth, rocks, water, wind, fire or thunder have their own väkis, as well as death, female sexuality or the forest with its animals. Skills of transformative activities are also powerful: iron and the blacksmith's forge, tar burning and wood chopping have väkis. In Lutheran Finland the church and churchyards, in Orthodox Karelia the 'saints', or the icons of saints, have it, which means that these holy objects may cause illnesses (Stark 2002: 47-50; Siikala 1992: 249, 283). Churchyard-väki, water$v \ddot{a} k i$, sometimes forest-väki, and occasionally even the väkis of tar burning or wood chopping appear as crowds in narratives. Some väkis - for example, female väki - are only implied to in norms and customs but are not mentioned by the name väki in popular texts. ${ }^{4}$

There have been made some efforts to delineate the development of a force to a personified crowd (Vilkuna 1956: 20) or vice versa (Krohn 1914: 65-67 et passim). ${ }^{5}$ Whether the image of visible or totally impersonal agent has been more plausible appears to depend on the context. Furthermore, I do not see these traditional images of $v \ddot{a} k i$ as a uniform idea, but a set of different ideas which have enough similar features to be handled as one phenomenon in the popular worldview. Väki seems to have been one explanation of the magical idea of contiguity. In other contexts, in other form, it is rather based on the idea of the intentionality or even inhabitants of certain places or elements. In archive texts - as in practice - the question of mechanism is usually neglected, the focus being rather on the status of the elements which have väki. Gener- 
ally, in rituals väki is understood as a force, and is understood as such also in common interaction. In narratives it is presented as a crowd. This does not mean that $v \ddot{a} k i$ as a crowd was only used in the metaphorical sense; it has been described in numerous memorates as an empirical supernormal agent.

In scholarly view on folk belief, $v \ddot{a} k i$ has a special significance in terms of worldview and social order. During the last two decades väki, as presented in rituals and incantations, has in Finnish research been approached as a substance presenting other worlds or sacred (or "set apart") elements and areas, as well as their impact on human life (Anttonen 1993, 1994; Tarkka 1994; 1998: 95-99; Stark 2002: 42-50; for a review of the research see also Koski 2003). The mechanism by which different entities in the surrounding world affect each other in magical thought has also been outlined with the idea of väki. From this point of view väki is approached as a dynamic potential residing in nature and in human beings as well as in inanimate objects (Apo 1998: 71; Stark-Arola 1997: 1998, 119-122; 2002). Väki is usually actualised in situations where two or more parties are opposed or confronted with each other. It represents the idea of an intentional nature or property of the entity in which it resides, and shows the mutual impact of any two elements which are in some way set apart from each other. Practically the question is about human relations to such natural and cultural phenomena that have a crucial impact to human well-being. Väkis are both ritually avoided and ritually utilised. The view on väkis is ambivalent, which is typical for the vernacular sacred (see Anttonen 1993: 36-37, 58-59).

\section{CONCEPTUALISING THE CHURCHYARD-VÄKI}

Comparing churchyard-väki with other väkis, the connection to church widens the possible range of meanings conveyed in narratives and harnessed in rituals. The question is not only about the relationship between the realms of the living and the dead but also about the authority and the sacred nature of the church. These questions belonged together because the Lutheran Church practically monopolised the graves and the practice of burial to its own hands. Consequently, the väkis of the church and the dead are in Lutheran Finnish tradition more or less the same phenomenon. Churchyard-väki is among other $v \ddot{a} k i$-beliefs a special case also because the idea of beings residing in churchyards is connected with the souls of the dead. Many informants have identified churchyard-väki with the dead, while others emphasize that these are not the same thing. Incorporating dead bodies in the churchyard-väki tradition has 
been particularly common in western Finland and it has remarkably increased the variation within the concept.

In the study of the descriptions of supernatural beings, it is important to note that in folk belief legends it is usual to mention the supernormal agent with hardly any description at all. Memorates are often rich in details, which, however, apply to the setting rather than to the extraordinary element. Churchyard-väki may be described as a glimpse of something grey or a sudden smell or some mysterious noises. A practical way to find out something about the essence of the supernormal agent in question is to study what it has been told to do, where to come from, and how to function. The churchyard-väki that a narrator claims having seen on the road and mistaken for humans is essentially different from the one which was carried along in a little sachet of graveyard soil.

Churchyard-väki is a commonplace popular concept - that is, a diffuse category with fuzzy edges. In Wittgensteinian family resemblance model of a popular category some members of the category may have nothing in common except that they share crucial qualities with other members, which, in turn, have similarities with each other (Wittgenstein 1999: 64-65). Figure 1 is applied from linguist Talmy Givón (1989: 37), who used it to present a radical Wittgensteinian interpretation of the structure of a popular category. The figure is, as Givón argues, insufficient to describe human categorisation. As such I find it useful as a first step to approach the conceptual variation, taking into account only one variable. We can take each circle for a single type of narrative or description. The figure shows in simplified form how the contents of the concept range from visible, even corporeal dead bodies to an invisible force.

dead bodies invisible power

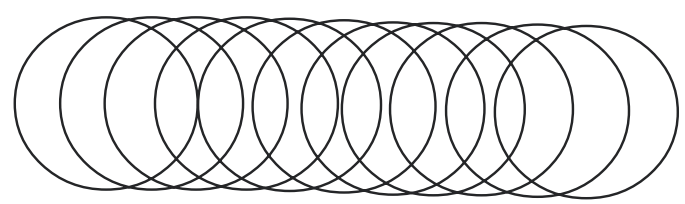

Figure 1. Talmy Givón's view on extreme Wittgensteinian category: insufficient to describe human categorisation but suitable for showing the variation on only one variable of a category, such as the physical essence of churchyard-väki. 
The so-called classical categorisation theory states that categories are formed by necessary and sufficient features, which every member of the category must have. The conditions of being a member are binary: an object either meets all of them or not. Thus there is no dispute of the members being all equally accepted (Taylor 1989: 22-24). But the problem lies in determining the suitable conditions for categories which we intuitively recognise. If we were to handle churchyard-väki as a classical category and make a list of sufficient and necessary qualities to determine it, we would have to decide between several options. What would be the most crucial features that the beings should definitely have to be still categorised as a churchyard-väki? For cartographic purposes, two such strict conceptualisations have been made. The first was made by Asko Vilkuna in 1956 and the other by Matti Sarmela in 1994. It is illuminating that they differ greatly from each other and that the resulting maps of the distribution of the churchyard-väki phenomenon ${ }^{6}$ accordingly showed remarkably different results. This is because Sarmela (1994: map 7) favoured the features typical for migratory legends about the dead, whereas Vilkuna (1956: $77,80)$ emphasised the force-like nature. These men represented the opposite ends of the above-shown Wittgensteinian model and refer to their categories by the same name. With this example they happened to map the geographical distribution of certain features and show that the classical categorisation model is not appropriate for describing such diffuse concepts.

According to the prototype theory, first introduced by psychologist Eleanor Ross in the 1970s, everyday thinking does not work with such a binary recognition. Natural categories in everyday thought are rather formed by analogy around prototypes. Some members are more central in the category whereas others are marginal, and the category boundaries are fuzzy. It means that in addition to typical members there are less representative ones and a plenty of almost members in the category (Rosch 1977: 20-26; Casson 1983: 434-435).

Elaborating on the prototype theory, George Lakoff stated that idealised cognitive models and their asymmetry with reality cause the so-called prototype effects, such as gradual membership, unclear edges and unequal representativeness of members in a prototype category. A polysemous concept is created when several ideational models are linked together. Polysemous concepts may have several prototypical cores instead of one (Lakoff 1987: 63-64; Koivisto-Alanko 2000: 24-26). Combining different categorisation theories, Talmy Givón sees category as a cluster of prototypes which share similar features. However, those features are not all equally important or necessary. According to Givón (1989: 36-40), the heart of the category is a core area, where the members share a greater amount of similar qualities than mem- 
bers in the margins. Following these advances in cognitive psychology and linguistics, we can move on to Figure 2 (see p. 55), which is a modification of Givón's other model using the ideas of George Lakoff.

Here I have distinguished between three most important prototypes of churchyard-väki. It means that there are three core areas in the category but many representations are still somewhere in-between. I have also added here the traditional genres in which each prototype is typically used, taking into account that narrative representations are also often something between idealised genres (cf. Briggs \& Bauman 1992: 148-149). Detailed descriptions are often totally absent in belief legends, but in addition to the variants in which $v \ddot{a} k i$ is described there are others in which the activities of väki reveal the type of the agent in question. The first prototype is a crowd of corporeal bodies identified with the dead. These beings either look like normal people or are heavily decomposing corpses or skeletons. Typically of migratory legends, this crowd attacks the living who enter their Christmas service (C 1341, C 1871) or who mock them at the churchyard gate (C 1101-C 1126). The next example of the legend about a Church service was recorded in Northern Finland (Lapland) in 1920. It does not include any physical description of the beings, but in the story it becomes evident that the crowd consists of individuals recognisable as dead humans. In the following example, the beings have been translated as the dead.

An old man went to the church of S., which doors were open. There were the dead playing their games. One came to tell him that this is not the church of the living now, this is the service of the dead. The dead one told him to hurry out and drop his fur coat on the threshold. Otherwise he would be killed. The old man did as he was told, dropped his fur coat on the threshold and got out. But for the coat it was the end. It was all destroyed. When people went to the church, the floor was covered with pieces of fur. The dead had thought that the old man was in the fur coat. (FLS. Sodankylä, Unari. Paulaharju, S. b. 14427. 1930)

The corporeal crowds are characteristic of legends only. In memorate versions of the same legend type, the encounter with the beings does not actually take place, or they are portrayed as less corporeal. Similarly, when the legend about a mocker at the churchyard gate is applied to a local churchyard, or is said to have happened to a local farmer, he rather escapes from a crowd of grey ghosts which disappear when he enters a cross-ploughed field. These ghosts already belong to the second prototype in my analysis. 
The second prototype is a crowd of small beings, moving in the air. This kind of churchyard-väki typically represents the order between the worlds of the living and the dead. This actively re-establishes the balance when something is on the wrong side of the border. Dead people belong to the side of the dead, but before a deceased person is buried and his or her status is ritually changed, the living have an unburied dead corpse amongst them. A churchyard-väki, swarming around the corpse, is an indication of this imbalance. Some informants claim that väki comes out from the dying or deceased person. According to this view, the churchyard-väki is not identified with the souls of the dead, while the idea of $v \ddot{a} k i$ as representative of the death and even the process of dying is stronger. However, väki has been more commonly described as a crowd that takes the deceased to the graveyard. A churchyard-väki has been said to come to the dying already before death, and also follow completely healthy people who are about to die a sudden death. Certain people, seers for example, have been believed to be able to see the churchyard-väki and recognise these omens of death. Other people can only smell them. Under the influence of the popular Christian tradition, according to which good and evil beings fetch the dead person's soul, churchyard-väki is often divided into black and white, especially in western Finland (Ostrobothnia). The association with the deceased person's actions or personality is expressed also by describing $v \ddot{a} k i$ as ugly or beautiful. By claiming to have seen black or ugly beings in the funeral procession, the seers employed certain social power.

In the realm of the visible, physical world inhabited by the living the churchyard symbolises the world of the dead - practically it is the territory of the dead, set apart from the everyday activities of the living. Another reason for the imbalance between the realms in the narratives is that some material objects which belong to the churchyard have been brought into or have remained in the everyday sphere. Such objects may be human bones, graveyard sand or pieces of memorial crosses, which cause haunting in the house or make the churchyard-väki return for the things. The churchyard-väki's role of keeping order is even clearer in narratives about drunkards who have been thrown over the churchyard fence or other breakers of norms who have been haunted by the churchyard-väki.

There are also descriptions of people who are for some reason constantly followed and haunted by the churchyard-väki. It is said that the väki has no bones, no flesh, but it torments its victim. It can be a punishment for violating the peace of the churchyard, or a contagion received when trying and failing in performing magic with the väki. A witch may have also intentionally summoned the väki upon somebody. Here we are approaching the third prototype: an agent with no intentions on its own is attached to tangible objects. 
The väki of the third prototype can be taken along or summoned by taking a little amount of churchyard soil or any death-related material. Leaving the material to an enemy's house resulted in its haunting the place. In addition to the mechanical action of causing noises wherever it was located, the väki could be given a purpose or some simple task to fulfil; for example, to chase thieves and make them return the stolen objects.

According to folk belief, a väki can also cause physical or mental illnesses, misfortune, or even death. For example, a rumour recorded in northern Finland tells of a house which inhabitants went insane because somebody had put human bones in their well (FLS. Vihanti. M.A. Junttila 618. 1954). In cases like this the image of $v \ddot{a} k i$ approaches the idea of a contagious, unidentifiable force. In narratives the source of a possible infection or haunting was more relevant than the question of whether the agent was unidentified or a specific crowd of beings, and so was the possible suspicion that it had been caused on purpose.

\section{THE SIGNIFICANCE OF CONCEPTUAL INCOHERENCE}

When asked about otherworldly beings by their name, the opinions of informants as to which words are synonymous or mark the same category have varied. Some names are generally used on two different levels of abstraction, on the one hand referring to a supernatural being in general and on the other hand to a specified being - even two or more specified beings in different contexts (see Koski 2004b: 104-105). Everyday cognition is economical, and people make categorical distinctions only where they find it relevant (Dougherty \& Keller 1982: 763-764). Conceptual analysis of words for churchyard-väki clearly shows that people have not found it relevant to distinguish between the otherworldly beings of this kind. Similarly, they have not associated in their mind individual narratives or ideas they have heard. This means that the representation of churchyard-väki has remained within the narrative frame in which it had been represented (cf. Dan Sperber's reflective beliefs and their meta-representation in Sperber 1996: 88-90; Cosmides \& Tooby 2000: 61-63; Koski 2004a: 6-7). In such restricted narrative worlds, the plausibility of the existence of supernormal phenomena has been judged separately each time according to the context in question. That the pleasing message of the narrative supports the belief in supernormal phenomena in such single cases is well expressed by Juho Oksanen, informant of Annikki Kaivola-Bregenhøj. Oksanen was known to be skeptical towards belief stories, but nevertheless was fond of 


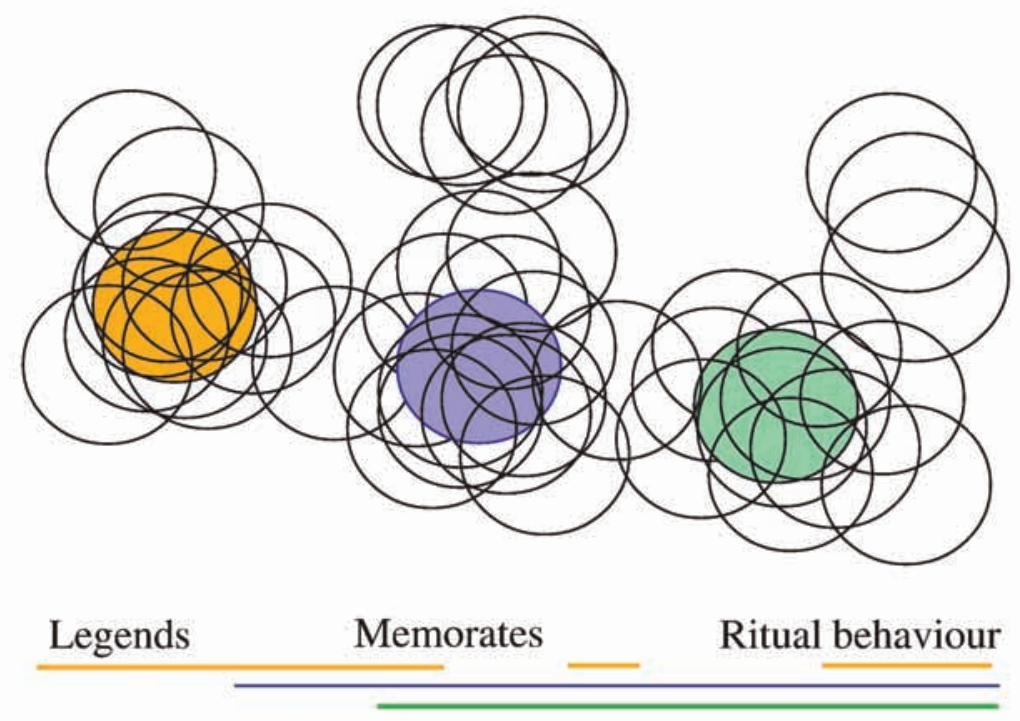

Figure 2. Structure of a polysemous category with three prototypical cores. The first of the cores consists of prototypical features typically represented in legends, the other rather in memorates. Prototypical features of the third core are found basically in rituals, but also in legends concerning rituals.

an anecdote about a cunning man who humiliated a local policeman with his magical skill. The humorous reversal of social hierarchy in the narrative made him include it in his active repertoire, and comment on the supernormal element as follows, I cannot explain it, but it was so nicely narrated that it almost makes me believe (Kaivola-Bregenhøj 1988: 89-91).

The incoherence presented above does not pervade all my material. Some accounts, such as personal memorates or descriptions of extraordinary individuals, imply that in some people's worldview, the churchyard-väki was a natural phenomenon and had a defined character. Many of these people have been professionals or other specialists, such as healers, washers of the dead or wise men or women. For each of them the image of the churchyard-väki was focused around their own speciality: usually it was either a grey swarm coming to fetch the dying, or a ritually controllable agent for magic and healing. For specialists in folk belief it was important to know the mechanisms according to which the supernatural forces were supposed to work and act towards each other. For laymen it sufficed to distinguish between this and the other world, and possibly take ordinary precautions against magic harm or bad luck (see 
Stark 2002: 44). In my research I have not focused on the more elaborate religious conceptions of the minority of specialists but rather on the ways that the majority has used the tradition in its normative discussions.

It is possible that one reason for the conceptual incoherence is that these ideas were losing their relevance on the threshold of modernisation. Still, they were found useful when discussing certain normative questions and interpreting local problems. Archived narratives only reflect the tradition during the time span from the late 19 th century until the 1960s. However, the old literal sources show no evidence that the concepts or their mutual relations had been more coherent before. When comparing the 20th-century materials with the Bible's Finnish translation ${ }^{7}$ from the year 1642, the foreword of the Psalms by Michael Agricola in 1551 (Agricola 1987), Christfrid Ganander's lexicon-like work Mythologia Fennica from 1789 (Ganander 1960) or other old lexicons (Ganander 1997, written in the 16th century but published only in the 20th century; Juslenius 1968 [1745], and Renvall 1826), I cannot see any considerable change in how these words were used. In my opinion, the conceptual incoherence tells that the status of these belief items has always been instrumental rather than constitutive.

According to Ludwig Wittgenstein, a category is a frame that tells in which light we are looking at the object. As a folklorist, I would categorise my material as accounts of the churchyard-väki but the narrators may have regarded them as narratives about something else: about venerating the dead; condemning magical practices or, to the contrary, expressing their admiration for its experts. Often the narratives have been comments on social relations, norms, extraordinary people or local events. In memorates, descriptions are shaped to become plausible for the audience, while in legends they are more likely to be dramatic. The churchyard-väki appears in each case in a form that best serves the narrative's point of view. Each prototype of churchyard-väki tends to be linked to certain stylistic or generic type of narration, as well as to certain plots and motives.

\section{VARIATION IN NORMATIVE ATTITUDES}

There is no need to romanticise the narrative situations in traditional agrarian societies. Legends were told in the evenings to pass time and frighten listeners. In addition, narratives connected to local places and people known by all listeners were used to comment on local incidents and social life. Spreading stories about violations of norms established by the churchyard-väki, or 
about funerary processions followed by black and ugly beings, share strong similarities with gossip. In small societies, questions about other people's morals constitute the kind of strategic information that, according to Boyer, make omniscient supernormal agents useful and worth believing in. ${ }^{8}$

In the previous section I have attempted to show that the single occasions in which the narrated contacts with the supernormal are realised and the normative messages which are conveyed by the narrated realisations of otherworldly contacts, have been in the tradition process more relevant than the supernormal agent itself. In my opinion, the incoherence of the concept - the fact that the properties of a supernormal agent are altered to match the needs of each given case - tells about the instrumental status of the supernormal agent. Still, the agents (such as the churchyard-väki) could not be replaced by other beings because they each tend to be linked not only to certain typical contexts and places but also to certain sets of traditional values and normative attitudes.

When we look at the normative points that the narratives concerning churchyard-väki convey, we will find contradictory attitudes, though mostly within certain thematic frames. Lauri Honko has argued that different views on the same subject are often genre-specific. Honko's example about this is death, on which laments provide a totally different view from the one expressed in belief legends (Honko 1979: 68-69). In the material used in this study, certain 'division of labour' between genres holds, but I wish to emphasise that belief legends alone also convey contradictory messages.

Confronted with the churchyard-väki, people are faced with the representatives of an alien world, the realm of death. In the following, the different attitudes towards the väki as based on mental models, which have regulated popular views on any boundary-crossing contacts, will be discussed. Such models may be overlapping or contradictory, competing with each other, or applied either together or separately in completely different contexts. Of course, the general thoughts and ideas which will be taken up here, such as ambivalence and ritual practices, have already been theoretically elaborated by numerous researchers, and their mutual relations have been presented also in a different light than here. My purpose is to outline the dynamics of these ideas in relation to the churchyard-väki, and for the sake of brevity, I will refer to former theories only where I have found it demonstrative for this purpose. I have distinguished between three major models of thought on which the attitudes towards the väki have been based.

The first model is the idea of ambivalence of sacred or otherworldly entities. This is what researchers have noted in ethnic religions a long time ago: The 


\section{Three mental models}

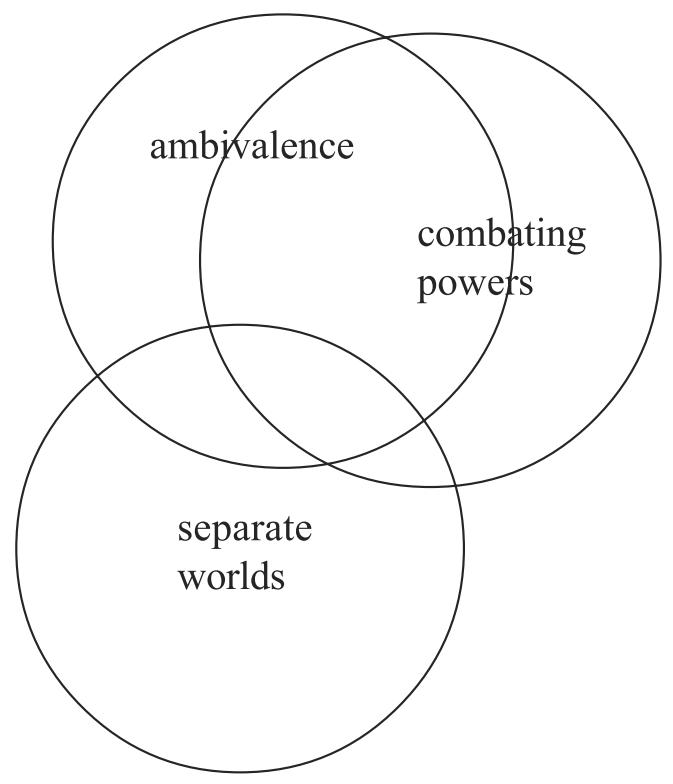

Figure 3. Three mental models concerning the attitude towards väkis, and their relationship to each other.

dead ancestors, as well as other otherworldly beings, are regarded both as harmful and friendly depending on the situation and on the way the contacts to them had been handled (Harva 1933: 100; Malinowski 1960: 95). The väki has been said to be potentially harmful but by ritual handling applicable to good use. The same idea has been proposed by the left-hand theorists of the sacred, who approached the sacred and the impure as one bipolar category. According to Georges Bataille (1988: 118-122), the classification is not stable: the places of the repulsive left and the attractive right sides can be ritually changed. For example, unburied corpses are ritually transformed into honoured ancestors. Veikko Anttonen has further emphasised the boundaries between the bipolar sacred and profane and has shown the sacred which is 'set apart' as another world or other territory. This uncontrolled and alien world is perceived both as a danger and a resource. The väkis express the impact of the places and elements that are socially regarded as sacred and are only ritually approachable (Anttonen 1993: 36-37, 58-59). ${ }^{9}$ 
The second model is the idea that every entity possesses a power of its own, and these powers can be ritually harnessed or suppressed. According to this old ethnic view, it does not only involve the opposition of the sacred and the profane, but the world is divided by numerous, often context-specific boundaries into different insides and outsides or other opposed parties, which can affect and harm each other by their power charge. The world is like a battlefield of different forces, and in order to ensure the safety and harmony in the house the inhabitants had to take it into account. From this point of view, manipulating the powers in one way or another - for example, to improve one's prosperity or to protect one from harmful powers - is not only permitted but also necessary. Especially when crossing a boundary, a protection by suitable forces - väkis - was important (see Apo 1995: 21-23; 1998: 71).

The third model follows the idea that entities which belong to different classes should remain separate. It is closely related to the idea that Mary Douglas constructed on the basis of the Old Testament as the normative system of ancient Jews - categories which are separate should remain separate. Douglas (1994: 51-58, 160) strongly argued against the bipolarity of the sacred, stating that pure categories are sacred, whereas impure and blended categories cannot become pure in any rituals. One reason for this conflict is that there is more than one conceptual basis for constructing the status of the sacred, and thus also various terms for it. Douglas's notion of the sacred (holy) as something whole and unblended has an entirely different conceptual ground than the sacred set apart, which practically coincides with the impure. ${ }^{10}$ In my material, these views are attached to two different, often opposing attitudes, which I have here approached as mental models.

The third model is often associated with Christian influences. In narratives it practically means that it is regarded as morally wrong to get involved with the other world, and people who have established relations with evil forces get severely punished. The norm is more often inferred to when magic rituals are said to have caused harm or problems for their practitioners. In the tradition related to death, the Lutheran idea that the living and the dead are not supposed to be in contact with each other is often applied. Catholic Christianity had shaped the ancient ancestral cult in a way that the Church became a mediator between the dead, who needed support in the afterlife, and the living, who were now advised to provide their dead with spiritual rather than material welfare (Wirkkala 1945: 19; see also Koski 2007: 108-109). Following the Reformation in the 16th century, the idea of taking care of the dead had to be rejected, which officially meant the end to the ancestral cult. By rejecting Purgatory, the Protestant Church also denied the possibility that the dead 
souls would return to earth as ghosts to atone for their sins. This meant that any ghosts trying to contact the living were to be understood as demons (Thomas 1971: 587-589). The Lutheran Church strongly disseminated the idea of the separation of the realms of the living and the dead, and the message was strengthened by belief legends in which the dead were portrayed as evil and aggressive (Simonsuuri 1963: 479; Sarmela 1994: 59). Fine examples of this are the legends of the Christmas service of the dead (C 1341, C 1871), where the dead - often referred to as the churchyard-väki - attack the living.

The third model is not rooted in the Christian influence only, since the second model of the world as a battlefield of forces is also based on the idea that separate realms may react violently towards each other, if not kept separate. The difference between these models lies in the attitude: whether people are allowed or not to take active role in manipulating the forces they might find useful.

\section{DIFFERENT ATTITUDES CONFRONTED}

An example of all three models applied together is the widely-spread legend about a witch or a wise man going to the church at night (D 311-D 331). There are several variants of the legend. The central theme in all the variants is that a person specialised in magic takes a layman with him and performs certain rituals before they can enter the church, inhabited by supernormal beings, at night. The purpose of going to the church at night is to obtain information or heal a patient with the help of supernormal powers or beings.

Here the church is applied a popular idea of ambivalence (the first model). The Christian view would be that the Church only represents the good and that its sacredness does not have a repulsive and polluting side. In vernacular tradition, however, the dark side is entailed in its sacred status and power. Thus the church is a dangerous place outside its proper ritual context, especially at night. The wise man complies with the second model as he enters the dangerous space to turn the harmful into the beneficial by his skills of magic. The third model is applied when the aggressiveness of the beings - the churchyard-väki, the dead, devils or church-spirits - is highlighted. If something goes wrong, the visitors scarcely escape from the evil beings. In other words, the visitors are about to get punished for getting involved with the other world. Good narrators have made use of the tension between the impudent courage of the wise man and the Christian morals. But the narrator can take the Christian side as well, and describe in an epilogue the wise man's horrible death in 
the hands of the devil, because he had sinned and desecrated the church (FLS. Konginkangas. Otto Harju 2348. 1938). ${ }^{11}$ Furthermore, there are other legend types that provide a parallel argument: that these specialists do wrong and are punished after their death (e.g. C 26, C231, C 291).

Sometimes, quite the opposite attitudes are expressed in different folklore genres. The churchyard-väki is used in fertility magic and healing without special warning about the possible risks or side effects they involve, whereas belief legends and memorates more often describe the failures and fatal consequences of such rituals. The third model's attitude expressed in them is, however, not necessarily based on Christian morals but on the social reasons for disapproving magic: in order to increase one's own luck one has to steal it from others. Emphasising the risks of active involvement in the supernatural may also aim at enhancing the reputation of the specialists. Therefore, the focus is on the special internal power and skills required for handling the väkis.

These examples of interpretive alternatives show that even the same legend types and motifs may speak for various opinions. The legends above agree in that at night a church is too dangerous for ordinary laymen. This is usually expressed by the scary appearance and behaviour of the beings in the church. Everything that is estranged from everyday sphere or disapproved in the narratives - the dead or practitioners of magic, for example - has been described in negative or even horrifying terms. The churchyard-väki has been portrayed in a completely different way in narratives, which are based on the idea of the naturalness of another world besides ours. From this point of view, churchyard-väki has been there all the time while most people just could not see it. The väki just "led a life of its own" (FLS. Säräisniemi. Anna Leinonen 8. 24) and caused problems only when the contact with the other world was somehow disturbed. Ritual manipulation of supernormal powers was one way of causing imbalance, especially if the väkis were irresponsibly let loose. In Christian versions, local magicians caused the imbalance and priests restored the order. In narratives sympathetic to ethnic religion, ritual practices seem to have been acceptable when carried out by someone skilful enough to do it properly. Rituals connected with everyday life and maybe even practised at home were described as simple and unproblematic. The more distant a phenomenon or a narrative motif was from the narrator's everyday life, the more frightening and dramatic was the description. This holds also to the variation in descriptions concerning the churchyard-väki. 


\section{COMIMENTS}

${ }^{1}$ Church-related names of churchyard-väki in Finnish are kirkonväki, kirkkomaanväki. Death-related names: kalmanväki, kalmalaiset, manalaiset, manhonväki, ruumiinhaltijat. Names suggesting the väki's lightness or invisibility: keijukaiset, keijulaiset, keijuset, keikkaat, tyhjäläiset, tyhjöset, näkymättömät. Names related to their appearance or actions: musta väki, päättömät, saattoväki, völjyväki, liikaväki. Other synonyms: männingäiset, menninkäiset, männingiläiset, mänkäläiset, hittuset, hönniläiset, settiset, intikat, etc.

${ }^{2}$ The tradition is the richest in Ostrobothnia, which is located along the northeastern coast of the Gulf of Bothnia. It is also well known in Savo, Central Finland, Kainuu and Finnish (Lutheran) Karelia, as well as in Lapland. In Orthodox Karelia the idea of $v \ddot{a} k i$ is known but not associated with the souls of the dead as it is the case in Lutheran areas. To the north and east of Ostrobothnia, väki is more often described as an invisible or translucent crowd, encountered in everyday surroundings, whereas in southern Ostrobothnia it has been more commonly influenced by narratives of the dead encountered in church or churchyard at night. In southwestern parts of Finland, the motif of the Christmas Mass held by the dead (C1341, C1821 in Jauhiainen 1998 ) is popular but not connected with the concept of väki.

${ }^{3}$ Short applications of the semantic analysis are published in Finnish in Koski 2004b.

${ }^{4}$ Satu Apo was the first to apply the concept of power or väki to interpret Karelian sexual discourse, e.g., incantations against "the wrath of the vagina" (Apo 1998: 66, 67; Apo 1995, 15; see also Stark-Arola 1998: 122). Laura Stark-Arola (2002: 72) adds also wind, village chapels and holy icons to the non-explicitly mentioned väkis in Karelian context. As such, the term väki has been used as terminus technicus, which usually only includes the meaning as a force. According to Touko Issakainen (2002: 111), väki, similarly to mana, has started a life of its own as a scholarly concept detached from its original folk belief contexts.

${ }^{5}$ Krohn argued that the $v \ddot{a} k i$ beings, as well as nature and household spirits, originate in the souls of the dead.

${ }^{6}$ Both researchers have used the synonymous term 'kalmanväki', which more explicitly expresses the connection to death in the Finnish language.

7 The words männingäinen and köpeli, used in Isaiah 34:14, are both polysemous. The meaning of these words in the Bible was determined by comparing the English, Swedish and later Finnish translations of the same verse (see also Pentikäinen 1968: 236).

${ }^{8}$ Boyer writes that people's own interests in social life make certain information of their fellowmen especially strategic. Supernatural agents are thought to have full access to this strategic information, such as deeds or thoughts hidden from other people. Boyer argues that there is an "empty place-holder" for such a supernatural agent to strengthen and explain the intuitive moral feelings that people have (Boyer 2002: 77-84). 
${ }^{9}$ On the sacredness of the useless, uncontrolled nature, as well as of the things left over from economic use see Anttonen 1994: 30.

${ }^{10}$ In Indo-European languages, one term marking the sacred is based on the positive value of wholeness, while the other is based on cutting off or setting apart. For an elaborate review on the semantics of the sacred see Anttonen 1996: 100-107.

11 This particular narrative was presented as an explicit evidence of God's power and portrayed cunning men in an exceptionally negative light. It told about a powerful preacher who had noticed "filthy games" having taken place on the altar of a church he had visited: a local sorcerer had skinned human bodies on the altar at night. $\mathrm{He}$ was given permission to preach the next Sunday and, despite the Devil's endeavours to silence him, sentenced the desecrator of the church to death. The story tells how the cunning man heard the words, far away at home, and realised he was to die before the church service ended.

\section{REFERENCES}

Agricola, Mikael 1987. Dauidin psaltari. Alcupuhe psaltarin päle. In: Lahja-Irene Hellemaa, Anja Jussila, Esko Koivusalo and Marja-Liisa Lamminsalo (eds.), Mikael Agricolan teokset. WSOY. Porvoo-Helsinki.

Anttonen, Veikko 1993. Pysy Suomessa Pyhänä. Onko Suomi uskonto? In: Teppo Korhonen (ed.), Mitä on suomalaisuus. Helsinki: Suomen Antropologinen Seura, pp. 33-67.

Anttonen, Veikko 1994. Erä- ja metsäluonnon pyhyys. Metsä ja metsänviljaa. Kalevalaseuran vuosikirja 73. Helsinki: Suomalaisen Kirjallisuuden Seura, pp. 24-35.

Anttonen, Veikko 1996. Ihmisen ja maan rajat. 'Pyhä' kulttuurisena kategoriana. Suomalaisen Kirjallisuuden Seuran toimituksia 646. Helsinki: SKS.

Apo, Satu 1995. Naisen väki. Tutkimuksia suomalaisten kansanomaisesta kulttuurista ja ajattelusta. Helsinki: Hanki ja Jää.

Apo, Satu 1998. "Ex cunno Come the Folk and Force": Concepts of Women's Dynamistic Power in Finnish-Karelian Tradition. In: Satu Apo, Aili Nenola \& Laura StarkArola (eds.), Gender and Folklore. Perspectives on Finnish and Karelian Culture. Studia Fennica Folkloristica. Suomalaisen Kirjallisuuden Seura. Helsinki, pp. 63-91.

Bataille, Georges 1988. Attraction and Repulsion II: Social Structure. In: Denis Hollier (ed.), The College of Sociology 1937-39. Minneapolis: University of Minnesota Press (1979), pp. 113-124.

Boyer, Pascal 2002. Why Do Gods and Spirits Matter at All? In: Ilkka Pyysiäinen and Veikko Anttonen (eds.), Current Approaches in the Cognitive Science of Religion. London \& New York: Continuum, pp. 68-92.

Briggs, Charles \& Bauman, Richard 1992. Genre, Intertextuality, and Social Power. Journal of Linguistic Anthropology 2(2), pp. 131-172.

Casson, Ronald W. 1983. Schemata in Cognitive Anthropology. Annual Review of Anthropology 12, pp. 429-462. 
Cosmides, Leda \& Tooby, John 2000. Consider the Source: The Evolution of Adaptations for Decoupling and Metarepresentations. In: Dan Sperber (ed.), Metarepresentations. A Multidisciplinary Perspective. Vancouver Studies in Cognitive Science. Vol. 10, pp. 53-115.

Dougherty, Janet W. D. \& Keller, Charles M. 1982. Taskonomy: A Practical Approach to Knowledge Structures. American Ethnologist 4/9, pp. 763-774.

Douglas, Mary 1994. Purity and Danger. An Analysis of the Concepts of Pollution and Taboo. London: Routledge.

Ganander, Christfrid 1960. Mythologia Fennica. Facsimile [1789] Helsinki: Suomalaisen Kirjallisuuden Seura.

Ganander, Christfrid 1997. Nytt Finskt Lexicon. From original manuscript, facsimile edited by Liisa Nuutinen. Helsinki: Suomalaisen Kirjallisuuden Seura \& Kotimaisten kielten tutkimuskeskus.

Givón, Talmy 1989. Mind, Code and Context. Essays in Pragmatics. New Jersey: Lawrence Erlbaum Associates.

Harva, Uno 1933. Altain suvun uskonto. Porvoo: WSOY.

Honko, Lauri 1979. Perinteen sopeutumisesta. Sananjalka 21. Turku, pp. 57-76.

Issakainen, Touko 2002. "Tulenväki on kaikkein väkevin, se kun polttaa niin kovasti” Kansanuskon väki-kategorian uudelleenarviointia. Sananjalka 44. Turku.

Juslenius, Daniel 1968. Suomalaisen Sana-Lugun Coetus. Facsimile [1745]. Helsinki: Suomalaisen Kirjallisuuden Seura.

Kaivola-Bregenhøj, Annikki 1988. Kertomus ja kerronta. Helsinki: Suomalaisen Kirjallisuuden Seura.

Koivisto-Alanko, Päivi 2000. Abstract Words in Abstract Worlds. Directionality and Prototypical Structure in the Semantic Change in English Nouns of Cognition. Mémoires de la Société Néophiloloque de Helsinki LVII. Helsinki: Société Néophiloloque.

Koski, Kaarina 2003. "Outoa, tuntematonta väkeä”. Näkökulmia väkeen tuonpuoleisen edustajana. Elore 1/2003. Available at http://cc.joensuu.fi/ loristi1_03/ kos103a.html, last accessed in 2008.

Koski, Kaarina 2004a. Arkiuskomukset - näkökulma arkiajatteluun. Elore 1/2004. Available at http://cc.joensuu.fi/ loristi/1_04/kos104.html, last accessed in 2008.

Koski, Kaarina 2004b. Monitulkintaisen aineiston ongelmia. Huomioita uskomustarinoiden luokittelusta. In: Tuulikki Kurki (ed.), Kansanrunousarkisto, lukijat ja tulkinnat. Helsinki: Suomalaisen Kirjallisuuden Seura, pp. 91-110.

Koski, Kaarina 2007. Döden och ondskan i den finska folktraditionen. Nord Nytt 100, pp. 101-123.

Krohn, Kaarle 1914. Suomalaisten runojen uskonto. Porvoo: WSOY. Suomalaisen Kirjallisuuden Seura.

Lakoff, George 1987. Cognitive models and prototype theory. In: Ulric Neisser (ed.), Concepts and Conceptual Development. Ecological and Intellectual Factors in Categorization. Emory Symposia in Cognition 1. Cambridge: Cambridge University Press, pp. 63-100.

Malinowski, Bronislaw 1960. Magia, tiede ja uskonto sekä muita esseitä. Porvoo \& Helsinki [1948]: WSOY. 
Pentikäinen, Juha 1968. The Nordic Dead-Child Tradition. Nordic Dead Child Beings. A Study in Comparative Religion. FFC 202. Helsinki: Academia Scientiarum Fennica.

Renvall, Gustavus 1826. Suomalainen Sana-Kirja. Lexicon linguae Finnicae, cum interpretatione duplici, copiosiore Latina, breviore Germanica. Vols. 1-2. Aboa: Frenckell.

Rosch, Eleanor 1977. Human Categorization. In: Neil Warren (ed.), Studies in CrossCultural Psychology. Vol. 1. London: Academic Press, pp. 1-49.

Sarmela, Matti 1994. Suomen Perinneatlas. Suomen kansankulttuurin kartasto 2. Helsinki: Suomalaisen Kirjallisuuden Seura.

Siikala, Anna-Leena 1992. Suomalainen šamanismi. Mielikuvien historiaa. Helsinki: Suomalaisen Kirjallisuuden Seura.

Simonsuuri, Lauri 1963. Uskomustarinat. In: Matti Kuusi (ed.), Suomen kirjallisuus I. Kirjoittamaton kirjallisuus. Helsinki: Suomalaisen Kirjallisuuden Seura \& Otava.

Sperber, Dan 1996. Explaining Culture: A Naturalistic Approach. Oxford: Blackwell Publishers.

Stark, Laura 2002. Peasants, Pilgrims, and Sacred Promises. Ritual and the Supernatural in Orthodox Karelian Folk Religion. Studia Fennica Folkloristica 11. Helsinki: Suomalaisen Kirjallisuuden Seura.

Stark-Arola, Laura 1997. Lempi, Fire, and Female Väki. An Exploration into Dynamistic Relationships in Finnish-Karelian Magic and Folk Belief. In: Anna-Leena Siikala and Jyrki Pöysä (eds.), Amor, Genus \& Familia. Kirjoituksia suullisen perinteen ja kansankulttuurin alalta. Elektroloristi 1/1997. Available at http://cc.joensuu.fi/ 〜oristi/1_97/sta197.html, last accessed in 2008.

Stark-Arola, Laura 1998. Magic, Body and Social Order. The Construction of Gender Through Women's Private Rituals in Traditional Finland. Studia Fennica Folkloristica 5. Helsinki: Suomalaisen Kirjallisuuden Seura.

Stark-Arola, Laura 2002. The Dynamistic Body in Traditional Finnish-Karelian Thought. Väki, vihat, nenä and luonto. In: Anna-Leena Siikala (ed.), Myth and Mentality. Studies in Folklore and Popular Thought. Studia Fennica Folkloristica 8. Helsinki: Suomalaisen Kirjallisuuden Seura, pp. 67-103.

Tangherlini, Timothy 1990. "It happened not far from here...": A Survey of Legend Theory and Characterization. Western Folklore Vol. 49, pp. 371-390.

Tarkka, Lotte 1994. Other Worlds - Symbolism, Dialogue and Gender in Karelian Oral Poetry. In: Anna-Leena Siikala \& Sinikka Vakimo (eds.), Songs Beyond the Kalevala. Studia Fennica Folkloristica 2. Helsinki: Suomalaisen Kirjallisuuden Seura.

Tarkka, Lotte 1998. Sense of the Forest: Nature and Gender in Karelian Oral Poetry. In: Satu Apo, Aili Nenola \& Laura Stark-Arola (eds.), Gender and Folklore: Perspectives on Finnish and Karelian Culture. Studia Fennica Folkloristica 4. Helsinki: Suomalaisen Kirjallisuuden Seura, pp. 92-142.

Taylor, John R. 1989. Linguistic Categorization. Prototypes in Linguistic Theory. Oxford: Clarendon Press.

Thomas, Keith 1971. Religion and the Decline of Magic. New York: Scribner. 
Vilkuna, Asko 1956. Das Verhalten der Finnen in 'heiligen' (pyhä) Situationen. FFC 164. Helsinki: Academia Scientiarum Fennica.

Wirkkala, Ilmari 1945. Suomen hautausmaiden historia. Porvoo \& Helsinki: WSOY.

Wittgenstein, Ludwig 1999. Filosofisia tutkimuksia. Porvoo \& Helsinki \& Juva: WSOY. [Original: Philosophische Untersuchungen, 1953.] 